\title{
STRN wt Allele
}

National Cancer Institute

\section{Source}

National Cancer Institute. STRN wt Allele. NCI Thesaurus. Code C107662.

Human ST RN wild-type allele is located in the vicinity of 2 p22.2 and is approximately 123

$\mathrm{kb}$ in length. This allele, which encodes striatin protein, maybe involved in calcium signaling or cell junction formation. 